\title{
STUDI KINERJA SOLAR WATER HEATER DOUBLE PLATE DENGAN ALIRAN ZIG-ZAG BERALUR BALOK
}

\author{
Rizki Ikhsan1, Sudjito Soeparman², Mega Nur Sasongko 3 \\ 1, 2, 3 Teknik Mesin, Universitas Brawijaya, Jl. MT Haryono No. 167, Malang (65145) - Indonesia \\ Telp./Fax: (0341) 554291 \\ E-mail: m.rizkiikhsan@ymail.com
}

\begin{abstract}
Solar energy can be used for water heating by using solar water heater application. Therefore, its still needs some modification due to its low efficiency. This modification can be done by replacing the conventional plate of solar collectors into a double plate with a zig-zag pattern. The results shown that along with the decreasing of water flow rates could significantly increase the useful energy (Qu). Initial temperature of water inlet could affect the generated maximum temperature. The highest mean efficiencies of double plate solar water heater with a zig-zag grooved beams pattern of $49.11 \%$ was gained in the flow rate of $700 \mathrm{~mL} / \mathrm{min}$.
\end{abstract}

Keywords: Solar radiation, double plate solar water heater, zig-zag flow, turbulence enhancer, heat transfer, useful energy, loss of energy, efficiency

\section{PENDAHULUAN}

Pemanas air tenaga surya yang dimanfaatkan untuk pengadaan air hangat bagi keperluan sehari-hari, bila dibanding dengan peralatan pemanas air yang menggunakan listrik maupun bahan bakar fosil terbilang sangat kompetitif, bila dilihat dari segi kepraktisan dan nilai ekonomis. Kendala utama pemanas air tenaga surya adalah biaya pengadaan awal. Sebagai contoh pemanas air berkapasitas 280 liter berharga berkisar Rp. 12.000.000,- untuk tipe yang menggunakan penutup kaca biasa, dan Rp. 15.000.000,untuk tipe yang menggunakan penutup kaca jenis temper light. Sedangkan produk import dipatok setidaknya dengan harga dua kali dari produksi dalam negeri untuk kapasitas yang sama. Mahalnya biaya pengadaan pemanas air tenaga surya berakibat hanya orang-orang dari kalangan menengah keatas yang mampu memiliki pemanas air tenaga surya.

Sebuah kolektor surya terdiri dari pelat penyerap yang memiliki konduktivitas thermal yang baik, dimana pelat penyerap dihubungkan dengan pipa-pipa yang mengalirkan fluida, dan sebuah atau lebih penutup tembus cahaya pada bagian atas kolektor. Energi radiasi matahari yang datang berupa gelombang elektromagnetik yang ditransmisikan melalui penutup transparan dan diubah menjadi panas oleh pelat penyerap, dimana bagian dasar dan sisi plat penyerap diberi isolasi. Panas yang diterima oleh pelat penyerap selanjutnya diteruskan ke fluida untuk dipanaskan.

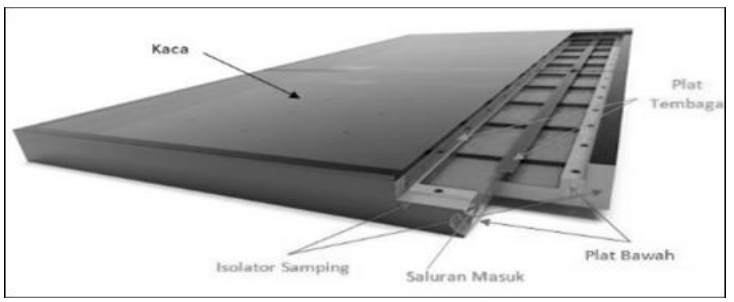

Gambar 1. Kolektor surya double plate

Parameter yang sangat berpengaruh dari kolektor surya pemanas air adalah absorber pada kolektor surya (Solar collector). Pada kolektor surya plat datar dengan absorber menggunakan pipa dibutuhkan pengelasan untuk menghubungkan pipa dan pelat kolektor agar memperluas luasan penerima panas. Sambungan las tersebut menimbulkan adanya tahanan thermal yang dapat menghambat perpindahan panas, dari pelat absorber ke pipa dan menyulitkan dalam proses pembuatan. Pemanas air memiliki efisiensi yang berbeda. Nilai efisiensi pemanas air tenaga matahari adalah perbandingan antara laju panas yang berguna $(Q u)$ yang dipindahkan ke fluida, dibagi dengan radiasi matahari pada luasan kolektor. Seperti persamaan untuk menghitung efisiensi dari kolektor plat datar [1] yang ditunjukkan dibawah ini ; 


$$
\eta=\frac{Q_{u}}{Q_{A b s}} 100(\%)
$$

Dari persamaan efisiensi diatas, juga dapat dijabarkan dalam persaman berikut ;

$$
\eta=\frac{\dot{m} c_{p}\left(T_{o u t}-T_{\text {in }}\right)}{G_{t} \cdot A_{c}} 100(\%)
$$

Keterangan:

$Q_{u} \quad=$ Energi berguna untuk memanaskan fluida melewati kolektor, (Watt)

$Q_{A b s}=$ Energi radiasi pada luasan kolektor, (Watt)

$\dot{m} \quad=$ Massa laju alir fluida, $(\mathrm{Kg} / \mathrm{s})$

$C_{p}=$ Kalor spesifik fluida, $\left(\mathrm{KJ} / \mathrm{kg} .{ }^{\circ} \mathrm{C}\right)$

$A_{c} \quad=$ Luasan kolektor, $\left(\mathrm{m}^{2}\right)$

$\mathrm{G}_{\mathrm{t}}=$ Intensitas radiasi matahari total $\left(\mathrm{W} / \mathrm{m}^{2}\right)$

$\mathrm{T}_{\text {in }} \quad=$ Temperatur air masuk, $\left({ }^{\circ} \mathrm{C}\right)$

$\mathrm{T}_{\text {out }}=$ Temperatur air keluar, $\left({ }^{\circ} \mathrm{C}\right)$

Pada persamaan diatas, energi yang berguna didapatkan dari perpindahan energi yang dapat diserap oleh absorber, kemudian diteruskan ke fluida. Sehingga salah satu cara untuk mengurangi kerugian energi dari kolektor plat datar menggunakan pipa pada permasalahan yang dijelaskan pada paragraf sebelumnya, maka dilakukan penelitian mengenai pengembangan dari double plate solar water heater.

Penelitian terdahulu yang telah dilakukan pada pemanas air plat ganda menghasilkan efisiensi penyerapan energi berguna lebih tinggi, dibandingkan efisiensi penyerapan panas solar heater konvensional [2]., namun hasil hubungan efisiensi dengan kondisi operasioanl (Ti-Ta)/Gt. pada solar water heater pelat ganda penurunannya lebih tajam dibandingkan dengan solar water heater konvensional. Sehingga efektifisanya berkurang. Untuk mengatasi hal itu dari penelitian pemanas air double plate dengan aliran zig-zag [3], yang dapat memperpanjang intasan fluida dapat mengatasi penurunan nilai efektifitas pada solar water heater dua plat.

Bentuk peningkatan efisiensi dan efektifitas yang juga dapat dilakukan terhadap pemanas air tenaga matahari ialah dengan cara menambahkan turbulence enhancer pada kolektor. Dengan adanya turbulence enhancer, maka dapat terjadi peningkatan konveksi panas pada fluida sehingga efisiensi dari pemanas air tenaga matahari dapat meningkat.

Studi eksperimental tentang friction factor dan heat transfer pada pemanas air tenaga surya dengan kolektor surya pelat datar dilengkapi dengan sekat $5 \mathrm{~cm}$ [4]. Data eksperimen yang diperoleh dibandingkan dengan yang diperoleh dari data tabung polos dan sekat $10 \mathrm{~cm}$. Menghasilkan koefisien perpindahan panas untuk tabung penyekat dengan sekat $5 \mathrm{~cm}$ lebih tinggi dari tabung polos dan sekat dengan $10 \mathrm{~cm}$ untuk sejumlah Reynolds number yang diberikan. Penggunaan sekat terbukti meningkatkan kinerja pemanas air tenaga surya.

Pengaruh turbulence promoter terhadap efisiensi pemanas air tenaga matahari pelat ganda [5]. Menghasilkan kenaikan nilai efisiensi yang dihasilkan lebih meningkat sebanyak $5 \%$ dari pada pemanas air tanpa turbulence promoter.

Dari penelitian terdahulu diatas, maka didapatkan dasar yang unik sehingga dilakukan dalam penelitian ini, guna meningkatkan nilai efisiensi dan efektifitas pemanas air yaitu, dari penggabungan aliran zig-zag, yang dapat berguna memperpanjang lintasan fluida, dan dengan alur balok agar terjadinya turbulence enhancer dalam aliran. Selain itu sebagai dasar untuk mendukung pelaksaan penelitian ini dari penelitian terdahulu yang dapat diambil antara lain pengaruh jarak kaca kepelat penyerap terhadap temperatur pelat yang menyatakan besar panas yang diterima [6]. Hasil penelitian yang didapat bahwa kaca dengan tebal $5 \mathrm{~mm}$ mampu menahan temperatur diantara kaca dengan pelat penyerap dengan penurunan suhu yang lebih lambat dibanding dengan kaca $3 \mathrm{~mm}$. Pelat penyerap untuk destilasi air laut. Dari beberapa bahan uji [7], didapatkan bahwa bahan tembaga yang dilapisi cat hitam doff mempengaruhi nilai koefisien penyerapan panas yang baik. Pengaruh ketebalan plat penyerap dan jarak antar pipa-pipa kolektor terhadap kinerja kolektor surya pelat datar [8]. Efisiensi sirip tertinggi dalam percobaan ini dihasilkan dengan konfigurasi ketebalan plat $1.2 \mathrm{~mm}$. Laju aliran air pada solar heater sederhana menggunakan pelat penyerap tunggal [9], menghasilkan semakin cepat laju aliran air menghasilkan kinerja solar heater lebih rendah, begitu pula sebaliknya.

\section{METODOLOGI PENELITIAN}

Berdasarkan latar belakang dan penelitian terdahulu, maka didapatkan inovasi baru dari pengembangan tipe double plate solar water heater. Dengan aliran zig-zag beralur balok. 
guna mendapatkan efisiensi yang lebih baik dari penelitian terdahulu. dimana hasil yang didapat pada penelitian ini, akan dilakukan perbandingan, dengan perbandingan data penelitian dari tipe konvensional solar water heater [5], seperti Gambar 2 dibawah ini.

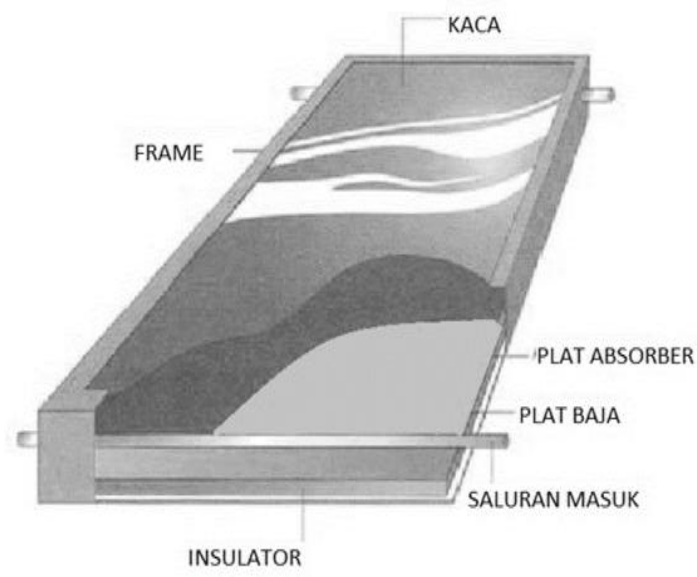

Gambar 2. Pemanas air plat ganda konvensional

Pengujian dilakukan secara experimental research. atau di lab. Tenaga surya Teknik Mesin Universitas Brawijaya. Dari pukul 08.00 WIB sampai dengan 15.00 WIB Dengan letak geografis : -7.950201 Latitude, dan 112.613059 longitude. variable bebas debit aliran fluida dengan variasi $700 \mathrm{~mL} /$ menit, $900 \mathrm{~mL} /$ menit, $1.000 \mathrm{~mL} /$ menit dan $1.500 \mathrm{~mL} / \mathrm{menit}$. Dan temperatur awal $\pm 30^{\circ} \mathrm{C}$ sampai temperatur stagnasi dari kolektor dengan kenaikan mengikuti perubahan temperatur keluar dari kolektor pemanas.

Alat dan bahan yang digunakan berdasarkan penelitan terdahulu, secara garis besar menggunakan kaca bening dengan ketebalan $5 \mathrm{~mm}$, plat tembaga dengan tebal 1,2 $\mathrm{mm}$ yang dicat hitam doff dan plat bawah menggunakan polyethylene dengan luas $0,5 \mathrm{~m}^{2}$ dengan tebal $25 \mathrm{~mm}$. Plat bawah tersebut di bentuk sesuai dengan bentuk yang akan diteliti seperti Gambar 3 berikut :

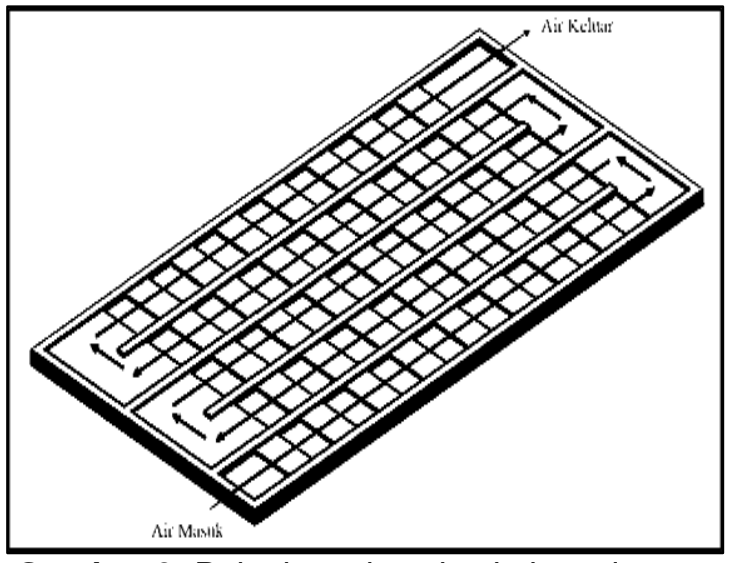

Gambar 3. Pelat bawah polyethylene dengan aliran zig-zag beralur balok

Sebelum melakukan instalasi pada solar water heater ada hal penting yang sangat diperlukan yaitu penentuan arah dan sudut kemiringan dari kolektor, karena solar collector harus terkena radiasi matahari langsung,agar di dapatkan solar irradiance yang optimum guna memanaskan bidang kolektor pemanas air. Hal pertama yang harus diketahui adalah letak geografis alat penelitian guna mendapatkan arah yang tepat. Dan kedua ialah menghitung sudut kolektor $(\beta)$ terhadap posisi deklinasi matahari. Berikut ilustrasi perletakan kolektor :

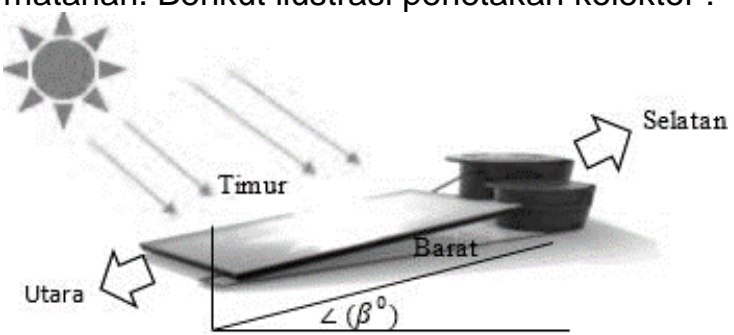

Gambar 4. Ilustrasi perletakan posisi kolektor surya yang terletak pada belahan bumi bagian selatan katulistiwa dengan bidang datar pada permukaan terhadap matahari. 


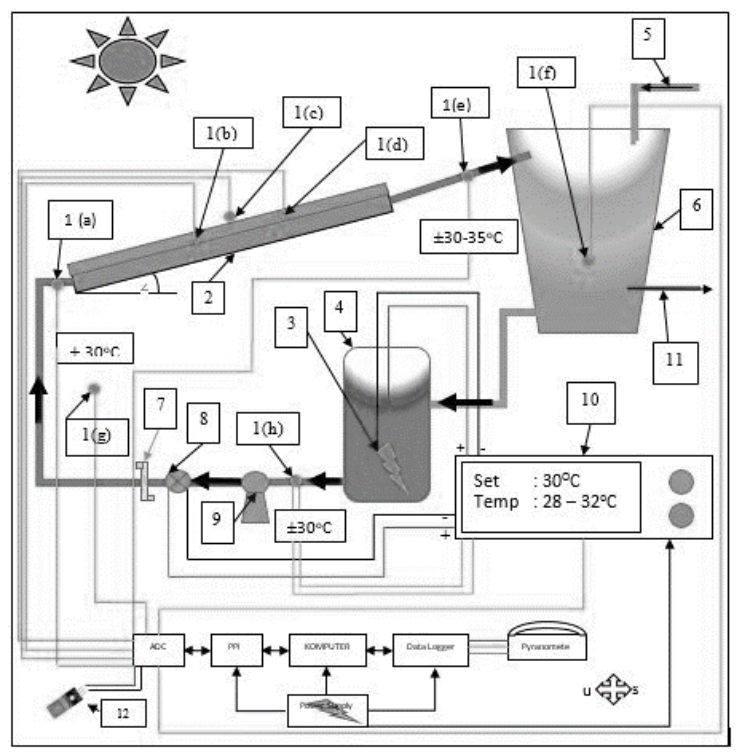

Gambar 5. Setup alat solar water heater double plate (tampak samping)

Keterangan :

1.Sensor termokopel pembaca suhu :

(a) Saluran masuk ke kolektor sesudah pompa $\left(\mathrm{T}_{\text {in }}\right)$

(b) Plat

(c) Kaca

(d) Antara kaca dan plat

(e) Saluran keluar dari kolektor ( $\left.T_{\text {out }}\right)$

(f) Bak penampungan

(g) Saluran pemanas awal sebelum pompa ke selenoid menuju saluran masuk kolektor

2.Kolektor

(h) Temperatur lingkungan

3.Element pemanas

4.Bak pemanas

5.Saluran sumber air

6.Bak penampungan air dari kolektor

7.Flowmeter

8.Katup dengan Selenoid

9.Pompa

10.Kontrol element pemanas dan pembaca temperatur suhu kolektor sebelum pompa

11.Saluran pemakai

12.Sensor kelembaban

ADC : Analog Digital Converter

PPI : Programable Periperal Interface

Pyranometer : Mengukur radiasi total matahari

\section{Prosedur memperoleh data}

Pada proses memperoleh data, peralatan sensor yang sudah diletakkan sesuai skema instalasi penelitian pada Gambar 5. Dikalibrasi terlebih dahulu untuk validitas data dan setiap harinya dilakukan pengecekan alat ukur dan kolektor dari kerusakan maupun kebocoran fluida untuk menghindari tidak validnya data yang diperoleh. Setelah dilakukan pemasangan dan pengecekan sensor dengan benar, maka dilakukan langkah pengecekan kebocoran air pada kolektor.

Proses pengambilan data pemanas dari kolektor yang dijelaskan pada Gambar 5 setup alat penelitian yaitu antara lain:

a. Pertama-tama melakukan pengisian air pada bak penampungan.

b. Menghidupkan pompa air.

c. Mengatur bukaan katup sebelum masuk kolektor, agar sesuai dengan variasi debit air masuk kedalam kolektor ( 1500, 1200, 900 dan $600 \mathrm{~mL} / \mathrm{menit}$ ). Guna mendapatkan debit aliran yang diinginkan. Debit diukur menggunakan flowmeter dan gelas ukur bersamaan dengan waktu pengukuruan.

d. Melakukan running program komputer untuk pencatatan data dengan durasi setiap 5 menit sekali, sampai waktu pengambilan data terpenuhi.

e. Membuka keran air dari bak penampungan agar air dapat mengalir menuju bak pemanas awal, selanjutnya menujut kolektor untuk dipanaskan oleh kolektor pemanas air tenaga surya.

f. Memvariasikan temperatur air masuk dengan range $\pm 5^{\circ} \mathrm{C}$ pada thermocontrol pemanas awal terhadap pemanas listrik. mengikuti tren kenaikan pada suhu air keluar dari kolektor, sampai suhu kritis / stagnasi (dimana tidak ada lagi penambahan temperatur keluar).

g. Setelah waktu pengambilan data dalam 1 hari selesai dilakukan, selanjutnya simpan data untuk diolah pada proses analisaan data. Membersihkan, mematikan arus listrik dan menutup alat penelitian, agar aman ditinggal untuk penelitian pada besok harinya. Selanjutnya pada besok harinya melakukan pengulangan point a sampai $\mathrm{g}$.

\section{HASIL DAN PEMBAHASAN}

Data yang diambil dalam penelitian pengujian bentuk kolektor pada double plate solar heater terdiri dari intensitas radiasi matahari, temperatur air masuk, temperatur air keluar, temperatur pelat penyerap, temperatur kaca penutup dan temperatur lingkungan. Pencatatan data dilakukan setiap 5 menit. Selanjutnya data dihitung, dibuat grafik dan dianalisis. 
I. Perubahan Energi Thermal Yang Terjadi kembali mendekati titik minimal. Hal ini

Dalam Penelitian Solar Water Heater diakibatkan oleh karena terjadinya rotasi bumi Double Plate Dengan Aliran Zig-Zag pada porosnya. Gerakan berputar bumi pada Beralur Balok. sumbunya kearah timur, atau bila dilihat dari

a. Bentuk Intensitas Energi Radiasi utara, bumi berputar melawan arah jarum jam. Matahari Harian Terhadap Waktu Putaran bumi pada porosnya mengakibatkan Pengambilan Data.

Dari data hasil pengujian data yang telah diambil dapat dibuat grafik dari bentuk intensitas energi radiasi sebagai berikut :
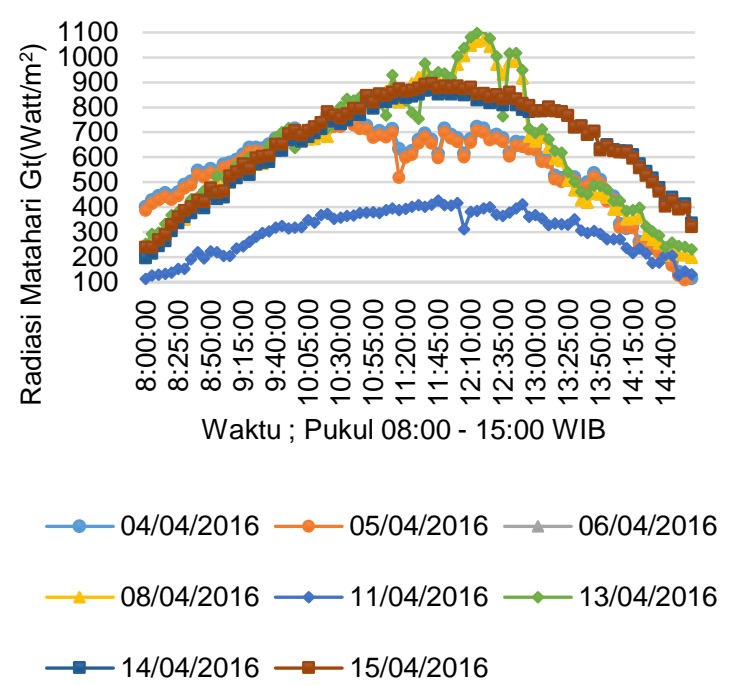

Gambar 6. Grafik intensitas radiasi matahari harian terhadap waktu pengambilan data

Pada Gambar 6 dilihat secara lebih spesifik, nilai data yang paling maksimal diperoleh pada penelitian tanggal 6 dan 8 april 2016. Pada pukul 12.15 WIB dan 12.20 WIB yang mempunyai nilai radiasi maksimal mencapai $1069,85 \mathrm{Watt} / \mathrm{m}^{2}$. Hasil pencataan data dengan nilai paling minimum tercatat tanggal 5 april 2016, pada pukul 15.00 WIB bersamaan dengan waktu akhir penelitian. Nilai radiasi terendah tersebut yaitu sebesar, 98,67 Watt $/ \mathrm{m}^{2}$.

Radiasi matahari harian yang dicatat oleh data logger melalui pyranometer selama pengujian cukup bervariasi. Pencatatan data diperoleh dari pukul 08.00 WIB hingga pukul 15.00 WIB. Hasil perolehan data yang dilakukan setiap 5 menit terlihat intensitas radiasi matahari setiap waktu mempunyai bentuk pola yang sama yaitu, rendah diawal dan mengalami peningkatan sedikit demi sedikit sampai mencapai titik maksimal. Setelah sampai dititik maksimal. Kemudian turun setiap daerah mengalami siklus siang dan malam.

Perubahan yang mengakibatkan Gambaran data mempunyai kestabilan dan ketidakstabilan. Seperti diambil contoh Gambaran, pada tanggal 11 April 2016, pukul, $08.00 \mathrm{~s} / \mathrm{d} 15.00 \mathrm{WIB}$. Dapat dilihat adanya kenaikan dan penurunan yang berbeda, sehingga terlihat bentuk kestabilan dan ketidakstabilan Gambaran data. Hal itu terjadi wajar terjadi, karena disebabkan oleh faktor alam yaitu; kondisi lintasan radiasi matahari. Dengan kondisi lintasan radiasi matahari mempunyai berbagai hambatan alami. Hambatan alami tersebut yaitu; kondisi cuaca, kelembaban, laju kecepatan angin dan lain-lain. Dengan adanya hambatan alami tersebut, akibatnya sejumlah energi matahari yang akan sampai kepermukaan mengalami hambatan. Karena faktor hambatan pada lintasan gelombang elektromagnetik, berakibat data energi yang datang setiap harinya mengalami perubahan yang stabil dan mengalami ketidakstabilan. Dan juga mengakibatkan tinggi dan rendah data yang berbeda-beda pula pada setiap waktu pencatatan datanya.

b. Rata-rata Perubahan Energi Pada Alat Penelitian Solar Water Heater Double Plate Dengan Aliran Zig-Zag Beralur Balok.

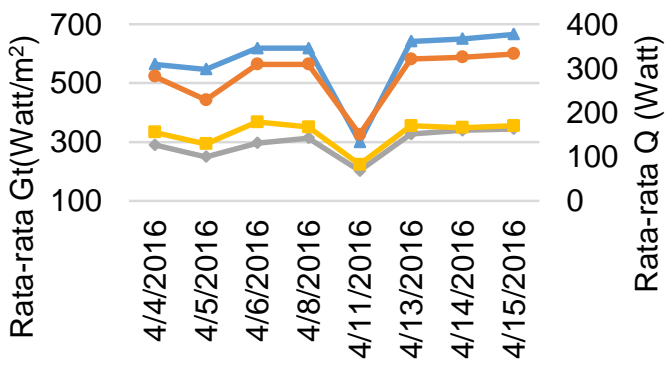

Tanggal

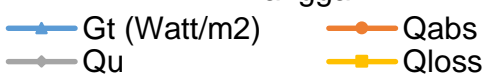

Gambar 7. Grafik rata-rata energi yang mampu diterima oleh luasan kolektor, energi berguna dan kehilangan energi terhadap energi matahari yang datang setiap hari 
Pada Gambar 7. Nilai rata-rata energi yang paling maksimal dihasilkan penelitian pada tanggal, 15 April 2016. rata-rata paling tinggi tersebut yaitu menghasilkan nilai; $\left(G_{t}\right)$ 666,39 Watt/m², (Qabs) 333,20 Watt, dan (Qu) 162,25 Watt. Kerugian rata-rata yang paling tinggi dihasilkan pada penelitian tanggal 6 April 2016 yang menghasilkan nilai rata-rata (Qloss) sebesar; 178,64 Watt. Energi paling minimum yang dihasilkan, terdapat pada penelitian tanggal ; 11 April 2016, Dimana menghasilkan nilai rata-rata minimum antara lain; $\left(\mathrm{G}_{t}\right) 300,01$ Watt $/ \mathrm{m}^{2}$, (Qabs) 150,00 Watt, (Qu) 67,93 Watt, dan (Qloss) 82,07 Watt.

Rata-rata energi dari radiasi matahari yang sampai pada kolektor setiap harianya, mempunyai nilai yang seimbang. Dimana ratarata energi radiasi yang datang mempunyai bentuk yang serupa, dengan energi yang mampu diterima oleh luasan kolektor. Namun nilai rata-rata energi yang berguna untuk memanaskan air mempunyai perbedaan pada setiap harinya. Hal ini dikarenakan adanya perbedaan laju aliran yang digunakan dalam penelitian. Dengan menggunakan variasi laju aliran yang berbeda-beda setiap dua kali pengambilan data, maka terjadi perubahan energi yang berguna. Begitu pula yang terjadi pada kehilangan energi, semakin banyak energi konveksi kalor yang dihasilkan, maka semakin minim kerugian kehilangan energi yang dihasilkan.

Kerugian kehilangan energi yang dihasilkan dengan menggunakan persamaan kesetimbangan energi [10], dari energi yang dapat diserap, dikurangi dengan energi yang berguna untuk memanaskan air. Dari data pada Gambar 7, meskipun didapatkan nilai maksimum dan minimum dan perubahan energi yang dihasilkan, namun masih dapat dikaji kembali untuk menunjukkan kinerja dan efisiensi yang hendak diketahui.

\section{Pengaruh Variasi Debit Aliran Dan Temperatur Awal Masuk Terhadap Efisiensi Yang Dihasilkan.}

a. Temperatur yang dihasilkan Dan Intensitas Radiasi Total Rata-Rata.

Temperatur rata-rata maksimal dihasilkan pada tanggal penelitian, 14 April 2016. Nilai maksimal temperatur rata-ratanya adalah; $T_{a m b}$ $32,15^{\circ} \mathrm{C}, \mathrm{T}_{\text {plat }} 59,68^{\circ} \mathrm{C}, \mathrm{T}_{\text {kaca }} 41,96^{\circ} \mathrm{C}$, $\mathrm{T}_{\text {in }}$ $56,06^{\circ} \mathrm{C}$, dan $\mathrm{T}_{\text {out }} 59,24^{\circ} \mathrm{C}$. Sedangkan nilai temperatur minimum yang dihasilkan pada penelitian cukup bervariasi, $T_{a m b}$ rata-rata minimum terdapat pada tanggal 5 April 2016, dengan nilai $28,66^{\circ} \mathrm{C}$. Tplat minimum pada tanggal 4 April 2016 , dengan nilai $39,88^{\circ} \mathrm{C}$. T kaca minimum pada tanggal 11 April 2016. Sedangkan rata-rata $T_{\text {in }}$ dan $T_{\text {out }}$ minimum terdapat pada tanggal 4 April 2016, dengan nilai rata-rata; $37,87^{\circ} \mathrm{C}$ dan $39,08^{\circ} \mathrm{C}$.



Gambar 8. Grafik rata-rata intensitas radiasi matahari dan temperatur rata-rata yang dihasilkan.

Pengaruh dari variasi temperatur awal dapat dilihat, pada Gambar grafik 8. Dengan memvariasikan temperatur awal, maka temperatur masuk tidak akan jauh selisihnya dari temperatur keluar. Selain itu, akibat dari memvariasikan temperatur awal, maka temperatur plat juga tidak akan jauh berbeda dengan rata-rata hasil dari temperatur keluar.

Penggunaan perpaduan variasi debit aliran dengan temperatur masuk, pada penelitian sangat berpengaruh. Dengan penggabungan dari variasi debit dan temperatur awal, maka dapat dilihat kembali pada Gambar grafik 8. Semakin besar debit dengan variasi temperatur awal, maka nilai rata-rata temperatur awal memiliki jarak selisih yang sedikit dengan temperatur akhir. Namun semakin kecil debit, dengan variasi temperatur awal, maka nilai rata-rata temperatur awal memiliki selisih jarak yang meningkat dengan temperatur akhir.

Penjelasan paragraf diatas, yang dapat dipahami adalah semakin kecil debit, maka 
untuk menyesuaikan variasi temperatur awal fluida masuk, terhadap temperatur fluida keluar terjadi delay waktu penyesuian temperatur. Karena nilai perubahan dari awal temperatur fluida masuk kolektor, sampai fluida keluar dari kolektor mengalami perubahan temperatur yang lebih cepat meningkat. Delay waktu penyesuaian temperatur awal masuk, bila dilihat dari bentuk alat kolektor pemanas, yang mempunyai aliran zig-zag beralur balok, sehingga dapat memperpanjang lintasan. Akibatnya, pada debit yang mengecil, penyerapan kalor konveksi pada fluida memiliki waktu yang cukup untuk memindahkan energi kalor konduksi dari plat kolektor. Selanjutnya bagaimana bentuk rata-rata efisiensi yang dihasilkan, terGambar pada pembahasan selanjutnya.

\section{b. Rata-rata variasi debit aliran dengan temperatur awal masuk terhadap efisiensi yang dihasilkan}

Dari data hasil penghitungan pada pengujian solar water heater double plate dengan aliran zig-zag beralur balok. Dapat dilakukan pembahasan pengaruh debit aliran dengan temperatur awal, pada penelitian terhadap efisiensi yang dihasilkan. Lebih jelasnya lihat pada Gambar 9 .



Gambar 9. Grafik rata-rata efisiensi terhadap variasi debit dengan temperatur awal masuk yang dilakukan pada penilitian

Pada Gambar 9 grafik efisiensi rata-rata dari variasi debit aliran dengan temperatur awal yang memiliki nilai maksimum, didapatkan dari variasi debit terendah yaitu pada variasi debit $700 \mathrm{~mL} / \mathrm{menit}$, dengan akumulasi nilai rata-rata mencapai $49,11 \%$. Sedangkan yang memiliki nilai minimum didapatkan pada variasi debit aliran yang lebih tinggi $1500 \mathrm{~mL} /$ menit, dengan nilai rata-rata $40,59 \%$.
Pembahasan sebelumnya, yang menunjukkan urutan-urutan hasil pembahasan pada penelitian, sehingga sampai pada pembahasan efisiensi yang dihasilkan. Dapat kita memprediksi hasil akhir efisiensi yang akan dapat. Bahwa nilai efisiensi yang lebih tinggi, dari penelitian solar water heater double plate dengan aliran zig-zag beralur balok. Adalah pada penelitian yang menggunakan debit aliran yang lebih kecil $(700 \mathrm{~mL} /$ menit), dengan hasil persentase efisiensi mencapai $49,11 \%$. Nilai efisiensi thermal maksimal tersebut hampir mencapai $50 \%$. Dari penggunaan alat yang sederhana, mengandalkan energi matahari sebagai sumber energi thermalnya, dan dengan waktu penelitian harian yang cukup lama. Memberikan nilai hasil akhir yang termasuk dalam kategori baik.

Pengaruh bentuk alat penelitian terhadap efisiensi yang dihasilkan. Ditunjukkan pada Gambar grafik 9, juga dapat dinyatakan bahwa dengan adanya aliran zig-zag beralur balok, maka terbukti bahwa bentuk aliran tersebut dapat memperpanjang lintasan aliran dalam kolektor, guna memindahkan energi thermal konveksi dari konduksi thermal plat kolektor. Dan dengan penambahan alur balok pada aliran zig-zag, juga dapat dibuktikan dari Gambar grafik 9, bahwa dengan penambahan permodelan tersebut pada alat, meski dengan laju aliran yang paling tinggi dari angka $1500 \mathrm{~mL} /$ menit, sampai pada penelitian dengan laju aliran yang lebih rendah, dengan angka $700 \mathrm{~mL} / \mathrm{menit}$, nilai efisiensi dari debit yang paling tinggi ke debit yang paling rendah tidak jauh selisihnya dan meningkat perlahan. Hal ini menyatakan bahwa, dengan adanya alur balok disepanjang aliran zig-zag dengan laju aliran yang tinggi, dapat meningkatkan nilai energi konveksi thermal dalam aliran fluida.

\section{Karakteristik Efisiensi Sepanjang Waktu Pengambilan Data Harian Terhadap Kondisi Operasional (Ti-Ta/Gt). \\ Dari data hasil penghitungan pada} pengujian efisiensi terhadap kondisi operasional, perhitungan rumus karakteristik alat pemanas menggunakan dasar literatur [1], ditunjukkan pada Gambar 10. Hasil paling maksimal dari Gambar grafik 10, didapatkan pada penelitian tanggal 4 April 2016 debit aliran $1500 \mathrm{~mL} / \mathrm{menit}$. Yaitu dengan efisiensi 
maksimal $83,42 \%$ pada kondisi operasional dengan arah yang tidak terlalu menurun 0,0066. Sedangkan hasil minimal didapatkan kebawah dapat disimpulkan, penurunan pada penelitian pada tanggal 5 April 2016, debit efisiensi kolektor menurun dengan lambat. aliran $1500 \mathrm{~mL} /$ menit, yaitu dengan efisiensi Sedangkan apabila garis trendline data lebih minimal $2,12 \%$, pada kondisi operasional panjang, dan arah penurunannya menuju 0,1121 .

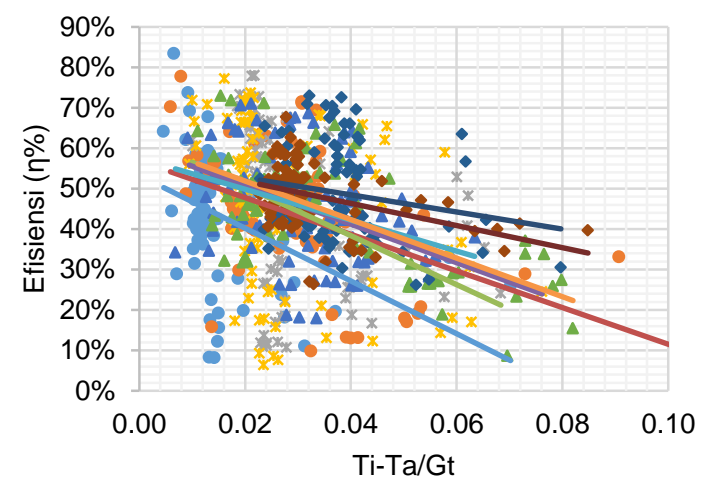

$$
\begin{aligned}
& \text { - } 04 \text { April } 2016 \quad 05 \text { April } 2016 \\
& \text { * } 06 \text { April } 2016 \text { * } 08 \text { April } 2016 \\
& \text { 4 } 11 \text { April } 2016 \text { \ } 13 \text { April } 2016 \\
& \text { - } 14 \text { April } 2016 \text { - } 15 \text { April } 2016 \\
& \text { _Linear (04 April 2016) _Linear (05 April 2016) } \\
& \text { _Linear (06 April 2016) _Linear (08 April 2016) } \\
& \text { _Linear (11 April 2016) L Linear (13 April 2016) } \\
& \text { _Linear (14 April 2016) LLinear (15 April 2016) }
\end{aligned}
$$

Gambar 10. Grafik karakteristik kinerja setiap waktu pengambilan data terhadap kondisi operasional $\mathrm{Ti}-\mathrm{Ta} / \mathrm{GT}$.

Perbandingan efisiensi dengan kondisi operasional pada Gambar grafik 10. Dapat dijelaskan bahwa, nilai efisiensi awal dari laju aliran yang paling tinggi mendapatkan nilai efisiensi yang paling tinggi pula. Namun mendekati akhir waktu penelitian nilai efisiensi dari debit aliran yang paling tinggi, mengalami penurunan drastis. Berbeda halnya dengan debit aliran yang paling rendah diawali dengan nilai efisiensi yang stabil dan tidak terlalu tinggi, namun pada waktu akhir penelitian nilai efisiensi cendrung masih stabil.

Kolerasi dari alat dan bahan dengan varibel penelitan, pada penelitian dari solar water heater double plate dengan aliran zig-zag beralur balok. Dari rangkuman hasil pembahasan nilai efisiensi terhadap kondisi operasional. Didapatkan hasil akhir yang sangat membantu dalam menarik kesimpulan dari penelitian ini. karakteristik kinerja dengan garis liner yang mempunyai garis lebih pendek kebawah mendekati sumbu $x$, dapat diartikan penurunan nilai efisiensi menjadi lebih cepat.

IV. Perbandingan Data Penelitian Solar Water Heater Double Plate Dengan Aliran Zig-Zag Beralur Balok Terhadap Data Hasil Penelitian Konvensional

a. Rata-rata Efisiensi yang dihasilkan dan rata-rata Intensitas Radiasi Matahari terhadap tanggal penelitian

Dari data hasil penghitungan pada penelitian solar water heater double plate dengan aliran zig-zag beralur balok yang disesuaikan jam dan jumlah data penelitiannya, dengan data pembanding pada kolektor pemanas air dua plat konvensional. Dapat dibuat grafik perbandingan rata-rata nilai efisiensi yang dihasilkan seperti ditunjukkan pada Gambar 11

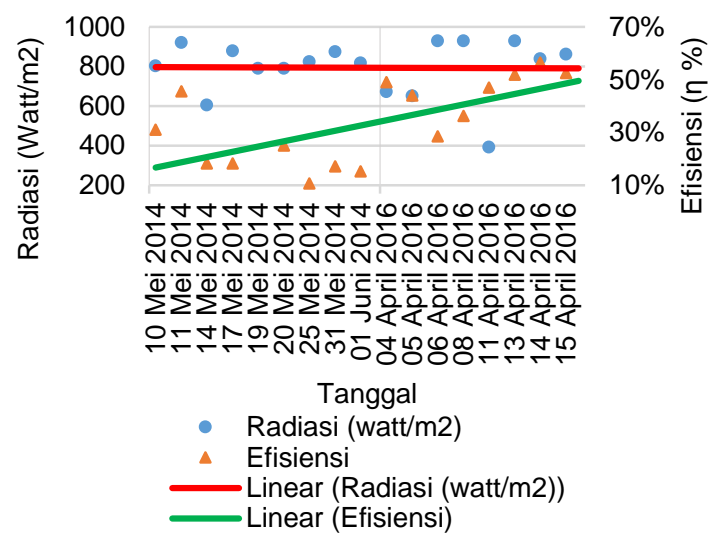

Gambar 11. Grafik rata-rata radiasi dan efisiensi rata-rata yang dihasilkan terhadap tanggal penelitian.

Dilihat pada Gambar 11, grafik rata-rata radiasi terhadap efisiensi yang dihasilkan terlihat jelas perbedaannya. Nilai rata-rata efisiensi yang paling maksimum didapatkan pada penelitian tanggal 14 April 2016, dengan efisiensi maksimum sebesar $56,42 \%$. Dan nilai rata-rata minimun didapatkan pada tanggal 19 Mei 2014, dengan nilai minimum sebesar $8,26 \%$. Sedangkan radiasi rata-rata yang maksimum didapatkan pada penelitian tanggal 
13 April 2016, dengan nilai rata-rata maksimun $9,28,95 \mathrm{Watt} / \mathrm{m}^{2}$. Radiasi rata-rata paling minimum dihasilkan pada penelitian tanggal 11 April 2016, dengan niali rata-rata minimum sebesar 391,05Watt $/ \mathrm{m}^{2}$.

Pada Gambar grafik 11, ditarik garis pembatas antara kedua perbandingan data yaitu, data yang diambil pada tanggal $10 \mathrm{Mei}$ 2014 s/d 1 Juni 2014 adalah data rata-rata dari penelitian pembanding konvensional. sedangkan data yang ditunjukkan pada pengambilan data tanggal 4 April 2016 s/d 15 April 2016 adalah rata-rata data dari hasil penelitian solar water heater double plate dengan aliran zig-zag beralur balok. Dari penarikan garis pembatas tersebut dapat dilihat adanya perbandingan yang sangat jelas kelihatan. Dan bila semua hasil efisiensi penelitian nilainya diakumulasi rata-ratanya dapat menghasilkan perbandingan nilai; $20,98 \%$ efisiensi dari alat konvensional. sedangkan solar water heater double plate dengan aliran zig-zag beralur balok menghasilkan akumulasi rata-rata efisiensi $45,65 \%$. Sehingga dapat dinyatakan bahwa, penelitian dengan model baru dari varian pemanas air plat ganda. Dengan inovasi bentuk aliran zig-zag beralur balok memiliki hasil efisiensi 2 (dua) kali lebih baik dibandingkan penelitian kolektor surya pelat ganda pada penelitian konvensional terdahulu.

\section{b. Karakteristik Efisiensi Sepanjang Waktu Pengambilan Data Terhadap Kondisi Operasional (Ti-Ta/Gt)}

Dari data nilai efisiensi terhadap kondisi operasional pada peletian dibandingkan dengan data pembanding, menghasilkan Gambar grafik seperti ditunjukkan pada Gambar 12. Pada Gambar grafik 12, penelitian solar water heater double plate zig-zag beralur balok memiliki selisih 2 kali lebih besar, dibandingkan dengan dua plat konvensional. Nilai tertinggi yang dihasilkan dimiliki oleh penelitian ini mencapai $72,95 \%$ pada saat kondisi operasional 0,0322 . Sedangkan nilai tertinggi yang dihasilkan pada data pembanding hanya $49,92 \%$ pada saat kondisi operasional menghasilkan nilai $-0,00373$. Nilai terendah yang dimiliki pada penelitan ini adalah $6,40 \%$, saat kondisi operasional 0,0235. Sedangkan nilai terendah yang dihasilkan pada data pembanding $2,73 \%$, saat kondisi operasional 0,00815 .



Gambar 12. Grafik rata-rata efisiensi terhadap $\mathrm{Ti}-\mathrm{Ta} / \mathrm{Gt}$.

Dari Gambar 12 pada keseluruhan data yang didapatkan menunjukkan penurunan nilai efisiensi seiring dengan semakin besarnya nilai $\mathrm{Ti}$-Ta/Gt. Apabila ditelaah lebih lanjut, tingkat kecuraman dari garis trendline dapat mewakili tingkat kestabilan alat untuk mempertahankan efisiensinya, seiring dengan berubahnya nilai $\mathrm{Ti}-\mathrm{Ta} / \mathrm{Gt}$. Semakin curam trendline yang terbentuk maka tingkat kestabilan alat akan semakin buruk, akan tetapi semakin landai trendline yang terbentuk maka tingkat kestabilan alat semakin baik. Didapatkan dari Gambar 12 data pembanding memiliki kestabilan alat yang kurang baik jika dibandingkan dengan data hasil penelitian ini. Dan nilai efisiensi yang dihasilkan oleh data pembanding, juga menghasilkan nilai yang lebih rendah dibandingkan dengan data penelitian ini.

\section{KESIMPULAN}

Berdasarkan hasil dan pembahasan dari penelitian yang telah dilakukan didapatkan kesimpulan sebagai berikut:

1. Intensitas radiasi matahari dan Variasi debit aliran berpengaruh terhadap energi yang dapat diterima oleh luasan kolektor dan energi berguna. Energi berguna tertinggi rata-rata dihasilkan kolektor, dengan variasi debit $700 \mathrm{~mL} / \mathrm{menit}$ dengan variasi temperatur masuk. Menghasilkan energi 
berguna sebesar $\left(Q_{u}\right)$ 162,25 Watt, dari ratarata energi yang dapat diterima oleh luasan kolektor sebesar (Qabs) 333,20 Watt. Sedangkan energi berguna minimum ratarata dihasilkan kolektor dengan variasi debit $900 \mathrm{~mL} / \mathrm{menit}$, dengan variasi temperatur masuk menghasilkan energi berguna sebesar $\left(\mathrm{Q}_{\mathrm{u}}\right)$ 67,93 Watt dari rata-rata energi yang dapat diterima oleh luasan kolektor sebesar (Qabs) 150,00 Watt.

2. Variasi temperatur awal berpengaruh terhadap temperatur maksimal yang dihasilkan. Hasil rata-rata akumulasi temperatur keluar maksimum yang dihasilkan, pada penelitian kolektor pemanas air adalah sebesar $48,27^{\circ} \mathrm{C}$.

3. Efisiensi solar water heater double plate dengan aliran zig-zag beralur balok, ratarata tertinggi dari penelitian terdapat pada variasi debit aliran $700 \mathrm{~mL} /$ menit dengan variasi temperatur awal masuk menghasilkan nilai efisiensi sebesar $49,11 \%$.

4. Penggunaan pemanas air dari varian solar water heater double plate, dengan aliran zigzag beralur balok, dibandingkan dengan hasil data konvesional. Menghasilkan perbandingan akumulasi nilai rata-rata efisiensi keseluruhan pengujian, 2 (dua) kali lebih baik dibandingkan dengan data konvensional.

\section{DAFTAR PUSTAKA}

[1] Duffie, J. A. \& Beckman W. A. 2013. Solar Engineering of Thermal Process Fourth Edition. New Jersey: John Wiley \& Sons, Inc.
[2] Mustafa, 2008, Studi eksperimen perbandingan kolektor pelat ganda dan kolektor konvensional terhadap kinerja solar water heater. Thesis, Malang: Jurusan Teknik Mesin FT Unibraw Malang.

[3] Mustafa \& Ismail, N. R. 2009. Pengaruh Laju Aliran Air Menggunakan Pelat Penyerap Ganda Dan Konvensional Terhadap Kinerja Solar Water Heater. PROTON. 1 (1): 23-27.

[4] Nayak, U. K., Roy, S. C., Paswan, M. K. \& Gupta, A. K. 2015. Heat Transfer and Flow Friction Characteristics of Solar Water Heater with Inserted Baffel Inside Tube. International Journal of Engineering Research \& Science (IJOER). 1 (4): 33-38

[5] Wiraradi, R. 2016. Pengaruh Turbulence Promoter Terhadap Efisiensi Pemanas Air Tenaga Matahari Pelat Ganda. Tugas akhir, Malang: Jurusan Teknik Mesin FT Unibraw Malang.

[6] Handoyo, Ekadewi Anggraini. 2001. Pengaruh Jarak Kaca Ke Plat Terhadap Panas Yang Diterima Suatu Kolektor Surya Plat Datar. JURNAL TEKNIK MESIN. 3 (2): 52-56.

[7] Subarkah Rahmad, 2001. Penelitian Absorber Solar Still Untuk Distilasi Air Laut, Skripsi, Malang: Jurusan Teknik Mesin FT Unibraw Malang.

[8] Kristanto, P. \& San, Y. K. 2001. Pengaruh Tebal Plat Dan Jarak Antar Pipa Terhadap

[9] Farid, A. \& Ismail, N. R. 2011. Pengaruh Pelat Penyerap Ganda Model Gelombang Terhadap Kinerja Solar Water Heater Sederhana. Widya Teknika. 19 (1): 12-15.

[10] Kreider. F. Jan and Kreith F. Solar Heating And Cooling Active And Passive Design. New York : McGraw-Hill 